\title{
Skrining Fitokimia dan Uji Aktivitas Antioksidan Ekstrak Etanol Daun Patikan Emas (Euprorbia prunifolia Jacq.) dan Bawang Laut (Proiphys amboinensis (L.) Herb)
}

\author{
Fendy R. Mondonga*, Meiske S. Sangia, Maureen Kumaunanga \\ aJurusan Kimia, FMIPA, Unsrat, Manado
}

KATA K UN C I

Euphorbia prunifolia Jacq

Proipys amboinensis (L.) Herb

Skrining Fitokimia

Antioksidan

\section{K E Y W O R D S}

Euphorbia prunifolia Jacq

Proipys amboinensis (L.) Herb

Screening Phytochemicals

Antioxidants

\begin{abstract}
A B S T R A K
Euphorbia prunifolia Jacq dan Proipys amboinensis (L.) Herb adalah dua jenis tanaman yang masih belum banyak dimanfaatkan oleh masyarakat karena kurangnya informasi mengenai kedua tanaman tersebut. Menurut informasi masyarakat tanaman patikan emas digunakan sebagai obat tradisioanal penurun kolestrol dan bawang laut digunakan sebagai obat anti kanker. Berdasarkan informasi tersebut dilakukan penelitian mengenai skrining fitokimia dan uji antioksidan dengan metode DPPH dari daun patikan emas dan daun bawang laut. Dari penelitian ini diperoleh hasil bahwa kedua tanaman tersebut mengandung senyawa metabolit sekunder. Untuk daun patikan emas mengandung fenolik, flavonoid dan steroid sedangkan daun bawang laut mengandung fenolik, flavonoid, steroid dan tanin. Pada penelitian ini juga dilakukan uji total kandungan flavonoid dan kandungan total fenolik dimana daun patikan emas mempunyai nilai lebih tinggi dari daun bawang laut. Untuk hasil pengujian aktivitas antioksidan dari daun patikan emas yaitu memperoleh nilai diatas 50\% sedangkan bawang laut dibawah 50\%.

A B S TR A C T

Euphorbia prunifolia Jacq and Proipys amboinensis (L.) Herb are two types of plants that are still not widely used by the community because of a lack of information about both of these plants. According to the information from society, gold patikan plant used as a cholesterol-lowering drug tradisioanal and sea onion used as an anti-cancer drug. Based on this information had been done the research about phytochemical screening and antioxidant testing by DPPH method of patikan gold leaf and scallions sea. This research showed that both of these plants contains secondary metabolites. For patikan gold leaf containing phenolic, flavonoids and steroids while scallions sea contains phenolic, flavonoids, steroids and tannins. In this research also tests the total flavonoid and total phenolic content which patikan leaf gold has a higher value than scallions sea. For the test results of antioxidant activity from gold patikan leaf obtaining a value above $50 \%$ and below $50 \%$ of sea onion.
\end{abstract}

$\overline{\text { AVAILABLE ONLINE }}$

sekunder yang terdapat dalam patikan emas dan bawang laut maka perlu dilakukan pengujian skrining fitokimia untuk mendeteksi senyawa-senyawa metabolit sekunder seperti alkaloid, fenolik, flavonoid, saponin, steroid, terpenoid dan tanin yang terkandung dalam tanaman tersebut. Menurut informasi masyarakat kota Tomohon mengenai patikan emas sebagai obat anti kolesterol dan bawang laut sebagai

*Corresponding author: Jurusan Kimia FMIPA UNSRAT, Jl. Kampus Unsrat, Manado, Indonesia 95115; Email address: meiske_sangi@yahoo.co.id Published by FMIPA UNSRAT (2015) 
obat anti kanker maka dilakukan pengujian aktivitas antioksidan dengan metode DPPH untuk melihat seberapa tinggi nilai antioksidan yang terkandung dalam kedua tanaman tersebut.

\section{Metode}

\subsection{Bahan dan Alat}

Alat-alat yang digunakan antara lain: timbangan analitik, blender, ayakan 65 mesh, oven, desikator, petridish, gelas kimia, gelas ukur, mikropipet, pipet mohr, vortex mixer, labu Erlenmeyer, rotary evaporator, magnetik stirer dan spektrofotometer UVVis (Milton Roy 501). Sampel yang digunakan yaitu daun patikan emas dan bawang laut yang diambil dari kota Tomohon dan Manado Sulawesi Utara. Bahanbahan kimia antara lain akuades, etanol, reagen Folin-Ciocalteu 50\%, $\mathrm{Na}_{2} \mathrm{CO}_{3} 2 \%, \mathrm{AlCl}_{3} 2 \%$ dan 1,1difenil-2-pikrilhidrazil (DPPH).

\subsection{Prosedur Penelitian}

\section{Preparasi Sampel}

Daun Patikan Emas dan bawang laut dicuci bersih, diiris tipis dan dikering-anginkan selama 1 minggu. Setelah kering, sampel digiling menggunakan blender hingga menjadi serbuk dan diayak menggunakan ayakan 65 mesh.

\section{Pengujian Kadar Air (Sudarmadji, 1989)}

Sebanyak 2 g sampel dimasukkan ke dalam oven pada suhu $105{ }^{\circ} \mathrm{C}$ selama 3 jam, selanjutnya dikeluarkan dari oven dan didinginkan dalam desikator selama 30 menit, kemudian berat sampel ditimbang. Perhitungan kadar air sebagai berikut: $\%$ Kadar Air $=\frac{\left(\mathrm{M}_{S}+\mathrm{M}_{T}\right)-\mathrm{M}_{T} 1 \times 100 \%}{\mathrm{M}_{T}}$

Ket:

Ms: Berat Cawan

Mт: Berat sampel serbuk belum dipanaskan

M 1: Berat cawan + sampel yang sudah dipanaskan

\section{Ekstraksi Sampel}

Ekstraksi dilakukan dengan cara maserasi. Sebanyak 25 g sampel serbuk dimasukkan ke dalam gelas erlenmeyer lalu ditambahkan pelarut etanol $250 \mathrm{~mL}$ hingga sampel terendam semuanya. Maserasi selama 24 jam kemudian disaring. Filtrat diuapkan untuk menghilangkan pelarutnya menggunakan rotary evaporator. Setelah itu ekstrak yang telah bebas pelarut dikeringkan dalam oven dengan suhu $40^{\circ} \mathrm{C}$ untuk memperoleh ekstrak kering.

\section{Skrining Fitokimia \\ -Pembuatan Pereaksi}

Pereaksi Mayer: Sebanyak 1,36 g $\mathrm{HgCl}_{2}$ dilarutkan dalam $60 \mathrm{~mL}$ akuades. Pada bagian yang lain larutkan pula $5 \mathrm{~g} \mathrm{KI}$ dalam $10 \mathrm{~mL}$ akuades. Kedua larutan ini kemudian dicampur dan diencerkan dengan akuades sampai $100 \mathrm{~mL}$. Reagen ini harus disimpan dalam botol yang berwarna coklat, agar tidak terjadi kontak langsung dengan cahaya.
Pereaksi Dragendorff: Sebanyak 8 g KI dilarutkan dalam $20 \mathrm{~mL}$ akuades, sedangkan pada bagian yang lain dilarutkan 0,85 g bismut subnitrat dalam $10 \mathrm{~mL}$ asam asetat glasial dan $40 \mathrm{~mL}$ akuades. Kedua larutan ini kemudian dicampurkan. Larutan disimpan dalam botol berwarna coklat. Dalam penggunaannya, larutan ini diencerkan dengan $2 / 3$ bagian larutan 20 $\mathrm{mL}$ asam asetat glasial dalam $100 \mathrm{~mL}$ akuades.

Pereaksi Wagner: Sebanyak 1,27 g I2 dan 2 g KI dilarutkan dalam $5 \mathrm{~mL}$ akuades. Larutan ini kemudian diencerkan dengan akuades hingga $100 \mathrm{~mL}$. Endapan yang terbentuk disaring dan disimpan dalam botol berwarna coklat.

\section{Uji Alkaloid}

Beberapa $\mathrm{mL}$ ekstrak daun (kering dan segar) tanaman patikan emas dan bawang laut, ditambahkan dengan $2 \mathrm{~mL}$ kloroform dan $2 \mathrm{~mL}$ amonia lalu disaring. Filtrat kemudian ditambahkan 35 tetes $\mathrm{H}_{2} \mathrm{SO}_{4}$ pekat lalu dikocok hingga terbentuk dua lapisan. Lapisan atas dipindahkan ke dalam tiga tabung reaksi masing-masing $2,5 \mathrm{~mL}$. Ketiga larutan ini dianalisis dengan pereaksi Mayer, Dragendorff dan Wagner sebanyak 4-5 tetes.

Terbentuknya endapan menunjukkan bahwa sampel tersebut mengandung alkaloid. Reaksi dengan pereaksi Mayer akan terbentuk endapan putih, dengan pereaksi Dragendorff terbentuk endapan merah jingga dan dengan pereaksi wagner terbentuk endapan coklat (Harborne, 1987).

\section{Uji Flavonoid}

Beberapa $\mathrm{mL}$ ekstrak daun (kering dan segar) tanaman patikan emas dan bawang laut, ditambahkan dengan $100 \mathrm{~mL}$ air panas, didihkan selama 5 menit, kemudian disaring. Filtrat sebanyak $5 \mathrm{~mL}$ ditambahkan 0,05 g serbuk $\mathrm{Mg}$ dan $1 \mathrm{~mL} \mathrm{HCl}$ pekat, kemudian dikocok kuat-kuat. Uji positif ditunjukkan dengan terbentuknya warna merah, kuning atau jingga (Harborne, 1987).

\section{Uji Steroid dan Triterpenoid}

Beberapa $\mathrm{mL}$ ekstrak daun (kering dan segar) tanaman patikan emas dan bawang laut, ditambahkan dengan $\mathrm{CH}_{3} \mathrm{COOH}$ glasial sebanyak 10 tetes dan $\mathrm{H}_{2} \mathrm{SO}_{4}$ pekat sebanyak 2 tetes. Larutan dikocok perlahan dan dibiarkan selama beberapa menit. Uji positif Steroid jika menghasilkan warna biru atau hijau, sedangkan triterpenoid menghasilkan warna merah atau ungu (Harborne, 1987).

\section{Uji Saponin}

Beberapa $\mathrm{mL}$ ekstrak daun (kering dan segar) tanaman patikan emas dan bawang laut, ditambahkan dengan $10 \mathrm{~mL}$ air sambil dikocok selama 1 menit, lalu ditambahkan 2 tetes $\mathrm{HCl} 1 \mathrm{~N}$. Bila busa yang terbentuk tetap stabil selama kurang lebih 7 menit, maka ekstrak positif mengandung saponin (Harborne, 1987).

\section{Uji Tanin}

Beberapa $\mathrm{mL}$ ekstrak daun (kering dan segar) tanaman patikan emas dan bawang laut, ditambahkan dengan 10 tetes $\mathrm{FeCl}_{3}$ 10\%. Ekstrak 
positif mengandung tanin apabila menghasilkan warna hijau kehitaman atau biru kehitaman (Harborne, 1987).

\section{Uji Total Kandungan Flavonoid}

Kandungan total flavonoid ekstrak etanol daun patikan emas dan bawang laut ditentukan menurut metode Meda et al., (2005). Sebanyak $2 \mathrm{~mL}$ larutan ekstrak $0,2 \mathrm{mg} / \mathrm{L}$ dan $0,5 \mathrm{mg} / \mathrm{L}$ dimasukkan dalam tabung reaksi lalu ditambah dengan $2 \mathrm{~mL} \mathrm{AlCl} 32 \%$ yang telah dilarutkan dalam etanol, kemudian divorteks. Absorbansi ekstrak dibaca pada spektrofotometer UV-Vis dengan $\lambda=415 \mathrm{~nm}$. Kandungan total flavonoid dinyatakan sebagai $\mathrm{mg}$ ekivalen kuersertin $\mathrm{mg} / \mathrm{mL}$ ekstrak.

\section{Uji Total Kandungan Fenolik}

Kandungan total fenolik ekstrak etanol daun patikan emas dan bawang laut ditentukan dengan menggunakan metode Folin-Ciocalteau (Conde et al., 1997). Sebanyak $1 \mathrm{mg} / \mathrm{L}$ dan 0,5 mg/L dimasukkan ke dalam tabung reaksi dan ditambahkan 0,1 reagen Folin-Ciocalteau 50\%. Kemudian vortex selama 3 menit dan ditambahkan $2 \mathrm{~mL}$ larutan $\mathrm{Na}_{2} \mathrm{CO}_{3} 2 \%$ lalu divorteks kembali. Selanjutnya campuran diinkubasi selama 30 menit pada suhu ruang. Absorbansi ekstrak dibaca pada spektrofotometer UV-Vis dengan $\lambda=750 \mathrm{~nm}$. Kandungan total fenolik dinyatakan sebagai $\mathrm{mg}$ ekivalen asam galat $\mathrm{mg} / \mathrm{mL}$ ekstrak.

\section{Uji Aktivitas Antioksidan}

Penentuan Aktivitas penangkal radikal bebas DPPH menurut Burda dan Olezek (2011). Sebanyak $0,5 \mathrm{~mL}$ ekstrak $1,0,5$ dan $0,2 \mathrm{mg} / \mathrm{L}$ daun patikan emas dan bawang laut ditambahkan dengan $2 \mathrm{~mL}$ larutan DPPH dan divortex selama 2 menit.

Tingkat berkurangnya warna dari larutan menunjukkan efisiensi penangkap radikal. Absorbansi dibaca dengan spektrofotometer pada $\lambda=517 \mathrm{~nm}$. Aktivitas penangkal radikal bebas dihitung sebagai persentase berkurangnya warna DPPH dengan menggunakan persamaan:

$$
\begin{aligned}
& \% \text { Aktivitas Antioksidan } \\
& =\left[1-\frac{\text { Absorbansi Sampel }}{\text { Absorbansi Kontrol }}\right] \times 100 \%
\end{aligned}
$$

\section{Hasil dan Pembahasan}

Rendemen yang diperoleh dari hasil ekstraksi menggunakan metode maserasi dengan pelarut etanol dapat dilihat pada Tabel1.

\begin{tabular}{|c|c|c|c|c|c|}
\hline \multirow{2}{*}{ Nama Sampel } & \multicolumn{2}{|c|}{ Warna Sampel } & \multicolumn{2}{|c|}{ Massa Sampel (g) } & \multirow{2}{*}{$\begin{array}{c}\text { Rendemen } \\
(\%)\end{array}$} \\
\hline & Sampel Serbuk & Ekstrak Kering & Sampel Serbuk & Ekstrak Kering & \\
\hline $\begin{array}{c}\text { Patikan Emas } \\
(\mathrm{PE})\end{array}$ & $\begin{array}{c}\text { Hijau } \\
\text { kecoklatan }\end{array}$ & $\begin{array}{c}\text { Hitam } \\
\text { Kehijauan }\end{array}$ & 20.0337 & 5.2713 & 26.31 \\
\hline $\begin{array}{l}\text { Bawang laut } \\
\text { (BL) }\end{array}$ & Coklat muda & $\begin{array}{c}\text { Hitam } \\
\text { Kehijauan }\end{array}$ & 20.0113 & 4.827 & 24.12 \\
\hline
\end{tabular}

Tabel 1 - Rendemen ekstrak etanol daun patikan emas dan bawang laut

Tabel 2 - Kadar Air pada daun patikan emas dan bawang laut

\begin{tabular}{|l|l|l|l|}
\hline No & Nama Sampel & Berat Serbuk & Presentase \% \\
\hline & Patikan Emas & 2.0037 & 11.83 \\
\hline & Bawang Laut & 2.0043 & 13.12 \\
\hline
\end{tabular}

Data Tabel 1 menunjukan bahwa rendemen tertinggi terdapat pada sampel patikan emas, hal tersebut dikarenakan kurangnya komponen polar yang terdapat pada daun bawang laut. Selain itu juga faktor yang mempengaruhi hasil rendemen yaitu ukuran sampel yang akan diekstraksi. Daun patikan emas lebih mudah untuk digiling dari pada bawang laut. Menurut Sembiring et al. (2006), semakin halus bahan yang digunakan maka akan semakin tinggi rendemen yang dihasilkan dari sampel tesebut. Pada perbesaran luas permukaan bertujuan juga untuk mempercapat pelarutan, mempercepat reaksi kimia, dan mempertinggi kemampuan penyerapan.

Berdasarkan pada Tabel 3 dapat dilihat bahwa daun patikan emas mengandung senyawa metabolit sekunder yaitu fenol, flavonoid dan steroid. Hal itu dapat dilihat dengan adanya perubahan-perubahan warna yang terjadi pada sampel yang menunjukan adanya senyawa metabolit tersebut. Pada pengujian yang dilakukan, untuk pengujian fenol menghasilkan warna hijau kehitaman, pada pengujian flavonoid mengalami perubahan menjadi warna jingga. Hal tersebut sesuai dengan pendapat Marliana et al., (2005) yang menyatakan bahwa apabila dalam identifikasi flavonoid dihasilkan warna merah sampai jingga, maka senyawa yang memberikan warna tersebut adalah flavon. Untuk steroid terjadi perubahan warna menjadi hijau yang menunjukan bahwa sampel positif mengandung steroid.

Berdasarkan Tabel 4 dapat dilihat bahwa dari hasil skrining fitokimia yang dilakukan, daun bawang laut memunyai kandungan senyawa metabolit sekunder yang terkandung pada ekstrak daun segar dan daun kering yaitu fenol, tanin, flavonoid dan steroid. Sedangkan alkaloid, terpenoid dan saponin tidak terkandung pada ekstrak daun segar dan kering 
tanaman bawang laut. Hal itu disebabkan tidak adanya perubahan yang terjadi pada sampel sesuai dengan yang ditentukan untuk mengetahui adanya alkaloid, terpenoid dan saponin.

Tabel 3 - Kandungan Senyawa Metabolit Sekunder Ekstrak daun patikan emas

\begin{tabular}{|l|l|l|c|c|l|}
\hline \multirow{2}{*}{ No } & \multirow{2}{*}{ Pengujian } & \multicolumn{2}{|l|}{ Hasil } & \multirow{2}{*}{ Keterangan } \\
\cline { 3 - 5 } & Alkaloid & P. Mayer & - & - & Tidak membentuk endapan putih \\
\cline { 3 - 5 } & & P. Dragendorff & - & - & $\begin{array}{l}\text { Tidak membentuk endapan merah } \\
\text { jingga }\end{array}$ \\
\cline { 3 - 5 } & P. Wagner & - & + & Tidak membentuk endapan coklat \\
\hline 2 & Fenolik & + & + & $\begin{array}{l}\text { Menghasilkan perubahan warna } \\
\text { menjadi hijau kehitaman }\end{array}$ \\
\hline 3 & Flavonoid & + & - & $\begin{array}{l}\text { Menghasilkan perubahan warna } \\
\text { menjadi jingga }\end{array}$ \\
\hline 4 & Tanin & - & $\begin{array}{l}\text { Tidak menghasilkan perubahan } \\
\text { warna menjadi hijau kehitaman } \\
\text { atau biru }\end{array}$ \\
\hline 5 & Steroid & + & $\begin{array}{l}\text { Menghasilkan perubahan warna } \\
\text { menjadi hijau }\end{array}$ \\
\hline 6 & Triterpenoid & - & $\begin{array}{l}\text { Tidak menghasilkan perubahan } \\
\text { warna menjadi merah atau ungu }\end{array}$ \\
\hline 7 & Saponin & - & - & Tidak membentuk buih yang stabil \\
\hline
\end{tabular}

Tabel 4 - Kandungan Senyawa Metabolit Sekunder Ekstrak daun bawang laut

\begin{tabular}{|c|c|c|c|c|c|}
\hline \multirow{3}{*}{$\begin{array}{l}\text { No } \\
1\end{array}$} & \multirow{2}{*}{\multicolumn{2}{|c|}{ Pengujian }} & \multicolumn{2}{|l|}{ Hasil } & \multirow{3}{*}{$\begin{array}{l}\text { Keterangan } \\
\text { Tidak membentuk endapan putih }\end{array}$} \\
\hline & & & \multirow{2}{*}{$\begin{array}{l}\text { Daun } \\
\text { Kering } \\
-\end{array}$} & \multirow{2}{*}{$\begin{array}{c}\text { Daun Segar } \\
- \\
\end{array}$} & \\
\hline & Alkaloid & P. Mayer & & & \\
\hline & & P. Dragendorff & - & - & Tidak membentuk endapan merah jingga \\
\hline & & P. Wagner & - & - & Tidak membentuk endapan coklat \\
\hline 2 & \multicolumn{2}{|l|}{ Fenolik } & + & + & $\begin{array}{l}\text { Berubah warna menjadi hijau kehitaman } \\
\text { atau biru kehitaman }\end{array}$ \\
\hline 3 & \multicolumn{2}{|c|}{ Flavonoid } & + & + & Berubah warna menjadi jingga \\
\hline 4 & \multicolumn{2}{|l|}{ Steroid } & + & + & Berubah warna menjadi hijau \\
\hline 5 & \multicolumn{2}{|c|}{ Terpenoid } & - & - & Tidak berubah menjadi warna merah \\
\hline 6 & \multicolumn{2}{|l|}{ Saponin } & - & - & Tidak membentuk busa stabil \pm 7 menit \\
\hline 7 & \multicolumn{2}{|l|}{ Tanin } & + & + & Berubah warna menjadi hijau kehitaman \\
\hline
\end{tabular}

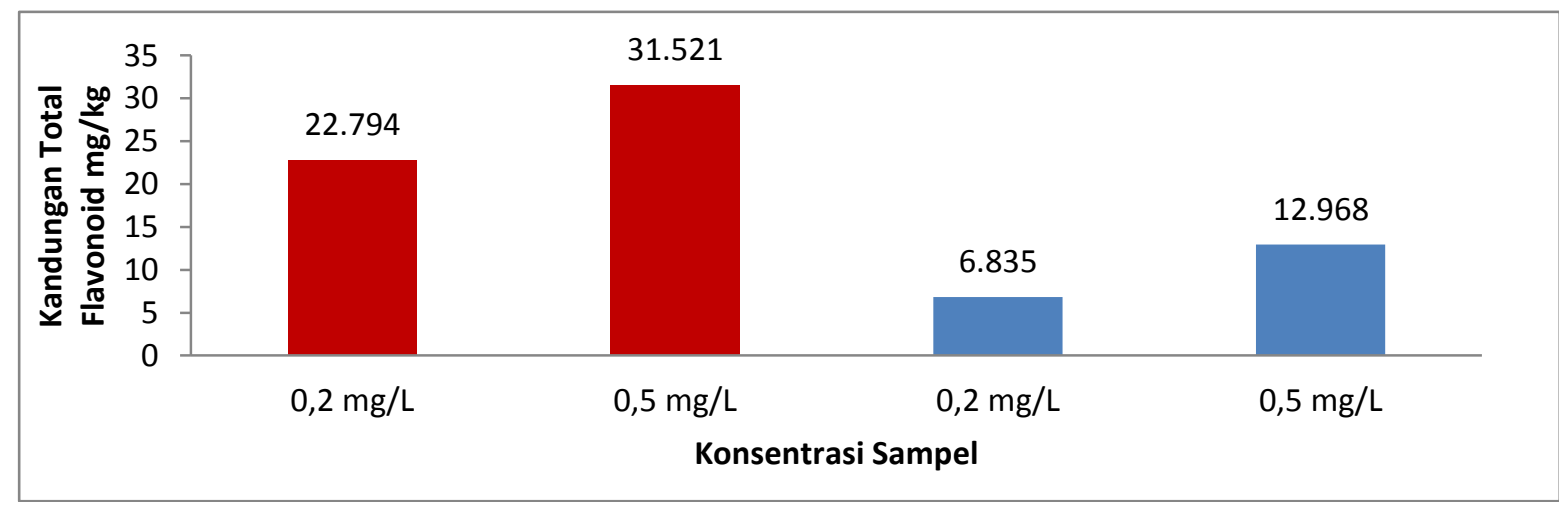

Gambar 1- Kandungan Total Flavonoid dari ekstrak daun patikan emas dan bawang laut 
Dari data Gambar 1 dapat dilihat bahwa kandungan flavonoid yang paling tinggi terdapat pada daun patikan emas dari pada daun bawang laut hal ini disebabkan karena kurangnya kandungan komponen polar yang terdapat pada sampel daun bawang laut sehingga membuat sampel tersebut mempunyai kandungan flavonoid yang rendah. Pengujian kandungan flavonoid menggunakan pereaksi $\mathrm{FeCl}_{3}$. Pereaksi $\mathrm{FeCl}_{3}$ bereaksi dengan ion fenolat dan membentuk ion kompleks (Singh, 2002).
Pereaksi ini spesifik untuk senyawa yang merupakan turunan dari fenol dan flavonoid yang merupakan turunan dari fenol. Dari hasil yang didapat bahwa bawang laut mempunyai kandungan flavonoid yang rendah dibandingkan dengan patikan emas diduga bahwa sampel bawang laut tidak bereaksi dengan baik sehingga kandungan flavonoid menjadi rendah. Dari hasil pengujian warna, patikan emas memiliki warna yang pekat dari bawang laut sehingga diduga juga mempengaruhi kandungan flavonoid.

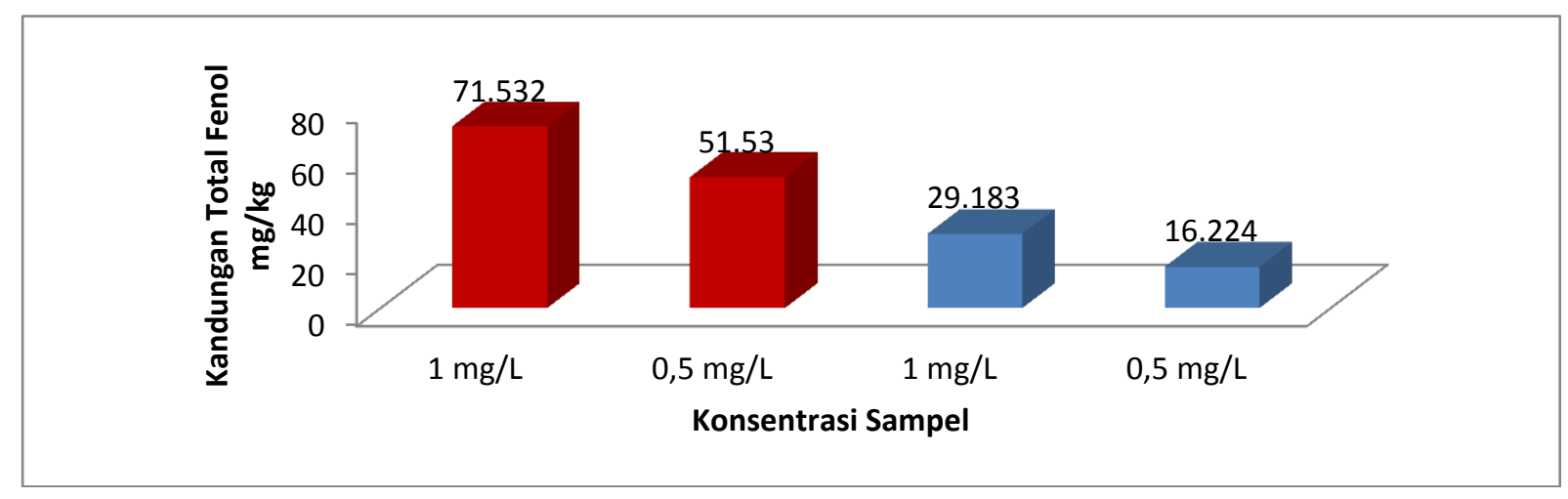

Gambar 2 - Diagram kandungan total fenol pada daun patikan emas dan bawang laut

Berdasarkan dari Gambar 2 dapat dilihat bahwa kandungan total fenol tertinggi terdapat pada daun patikan emas dari pada daun bawang laut. Pengujian dilakukan dengan dua konsentrasi yang berbeda yaitu $1 \mathrm{mg} / \mathrm{L}$ dan $0,5 \mathrm{mg} / \mathrm{L}$. Fenol merupakan suatu senyawa yang dapat bereaksi dengan senyawa pengoksidasi. Kemampuan tersebut menjadi dasar dengan digunakannya metode Folin-Ciocalteau. Prinsip dari metode tersebut adalah mengoksidasi gugus hidroksil pada fenol. Pereaksi tersebut mengoksidasi fenolat dan tereduksi menjadi suatu kompleks molindenum-tungsten (Mo-W) (Folin dan Ciocalteau, 1927).

$$
\begin{gathered}
\mathrm{Na}_{2} \mathrm{WO}_{4} / \mathrm{Na}_{2} \mathrm{MoO}_{4} \rightarrow\left(\text { Fenol }-\mathrm{MoW}_{11} \mathrm{O}_{40}\right) \\
\mathrm{Mo}(\mathrm{VI})_{(\text {kuning })} \rightarrow \mathrm{Mo}(\mathrm{VI})_{(\text {biru })}
\end{gathered}
$$

Gambar 3 - Reaksi Mo dalam reaksi antara reagen Folin-Ciocalteau dan senyawa Fenol (Folin dan Ciocalteau, 1927).

Singleton dan Rossi (1965) mengatakan bahwa Reagen Folin-Ciocalteau merupakan suatu larutan kompleks yang terbentuk dari fosfomolibdat dan asam heteropoli-fototungstat yang dapat mengoksidasi gugus hidroksi yang terkandung dalam sampel. Dari reaksi antara Reagen Folin-Ciocalteau dan gugus hidroksil dalam senyawa fenolik tersebut menghasilkan senyawa kompleks fosfotungstatfosfomolibdat yang berwarna biru dengan struktur yang belum bisa ditentukan dan hanya dapat dideteksi dengan spektrofotometer. Reaksi yang terjadi dapat dilihat pada Gambar 3.

Adanya warna biru dalam sampel menunjukan kandungan fenol yang terdapat dalam sampel tersebut. Semakin pekat warna biru yang dihasilkan maka kandungan fenol akan semakin tinggi. Singleton dan Rossi (1965) mengatakan bahwa warna biru yang diamati berbanding lurus dengan konsentrasi ion fenolat yang terbentuk, semakin besar konsentrasi senyawa fenolik maka semakin banyak ion fenolat yang terbentuk sehingga warna biru yang dihasilkan menjadi semakin pekat. Reagen Folin-Ciocalteau merupakan pereaksi yang tidak stabil pada kondisi basa, sedangkan ion fenolat hanya terdapat pada larutan asam, sehingga diperlukan penambahan $\mathrm{Na}_{2} \mathrm{CO}_{3}$ yang bertujuan untuk membuat suasana basa pada sampel sehingga reagen Folin-Ciocalteu akan tereduksi oleh gugus hidroksil dari fenolik yang terdapat dalam sampel.

Dari hasil penelitian yang didapat bahwa patikan emas memiliki kandungan fenol yang lebih tinggi, hal itu sejalan dengan hasil flavonoid yang didapat bahwa patikan emas memiliki kandungan fenol yang tinggi juga. Hal itu disebabkan flavonoid merupakan golongan fenol terbesar (Singh, 2002). Hasil presentase aktivitas antioksidan dari daun patikan emas dan bawang laut dapat dilihat pada Gambar 4.

Dari data hasil yang ada pada Gambar 4 dapat dilihat bahwa pada daun patikan emas mempunyai aktivitas yang lebih baik dari pada daun bawang laut. Dari hasil pengujian warna, terdapat perbedaan dari

*Corresponding author: Jurusan Kimia FMIPA UNSRAT, Jl. Kampus Unsrat, Manado, Indonesia 95115; Email address: meiske_sangi@yahoo.co.id Published by FMIPA UNSRAT (2015) 
kedua sampel tersebut yaitu, kandungan warna ungu masih lebih banyak terlihat di sampel bawang laut daripada sampel patikan emas. Pada saat larutan ekstrak ditambahkan dengan larutan DPPH, terjadi reaksi yang ditunjukkan dengan adanya perubahan warna, warna tersebut adalah warna ungu yg berubah menjadi warna kuning. Reaksi yang terjadi adalah senyawa yang memiliki antioksidan melepaskan atom hidrogen. Atom hidrogen yang ditangkap oleh senyawa radikal DPPH yang berwarna ungu. Setelah menangkap atom hidrogen senyawa radikal DPPH berubah menjadi senyawa non radikal yang berwarna kuning.

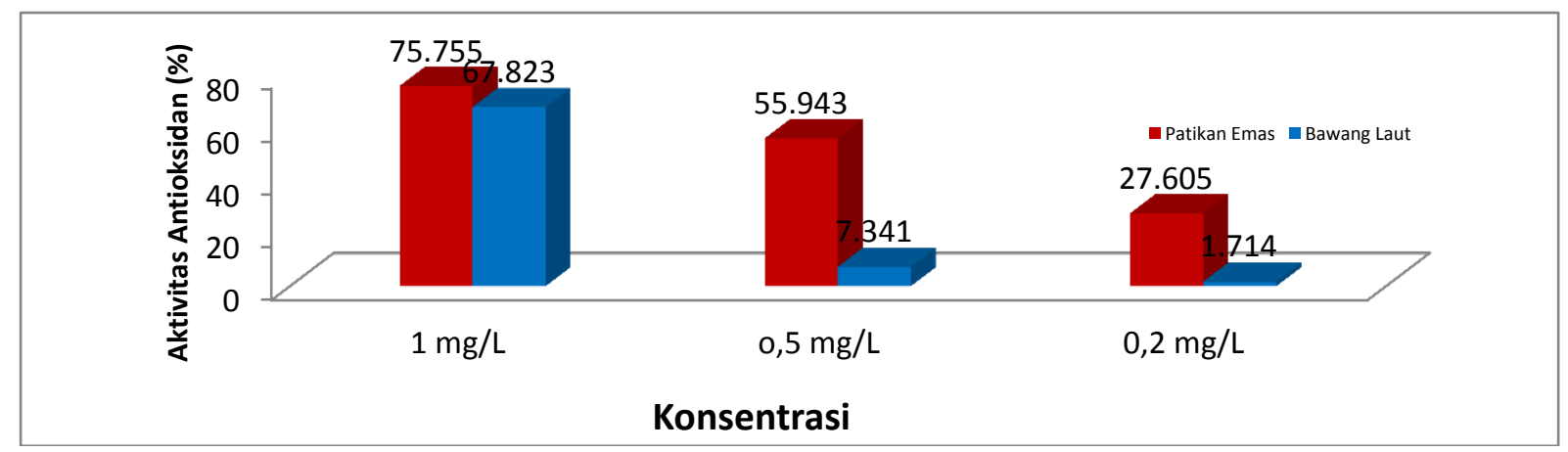

Gambar 4 - Diagram aktivitas antioksidan pada daun patikan emas dan bawang laut

Pada pengujian yang dilakukan, kedua sampel dibuat menjadi tiga konsentrasi yang berbeda yaitu $1 \mathrm{mg} / \mathrm{mL}, 0.5 \mathrm{mg} / \mathrm{mL}$ dan $0.2 \mathrm{mg} / \mathrm{mL}$. Dari pengujian tersebut didapat bahwa dalam setiap konsentrasi yang diuji, hasilnya sejalan yaitu nilai patikan emas selalu lebih unggul dari pada bawang laut. Sebelumnya dari hasil pengujian kandungan total fenolik dari kedua sampel didapat bahwa patikan emas memiliki kandungan total fenolik yang lebih baik, hal itu sejalan dengan kandungan aktivitas antioksidan yang didapat bahwa patikan emas mempunyai kandungan antioksidan yang baik karena senyawa fenol mempunyai peran penting dalam pembentukan senyawa antioksidan. Selain komponen-komponen dalam sampel, penggunaan pelarut juga ikut dalam salah satu faktor yang mempengaruhi kualitas dari antioksidan tersebut. Pemilihan pelarut yang baik dalam ekstraksi berpengaruh terhadap penghambatan radikal bebas. Pelarut etanol memberikan hasil bagus dalam ekstraksi kali ini. Pelarut etanol dapat menghambat radikal bebas DPPH. Hal tersebut sesuai dengan penelitian yang dilakukan oleh Tomsone et al. (2012) dalam penelitiannya pada tumbuhan lobak dengan beberapa macam pelarut dan terbukti bahwa etanol merupakan pelarut yang baik. Pada saat direaksikannya sampel dengan larutan DPPH terlihat bahwa warna dari larutan ekstrak yang ditambahkan dengan larutan DPPH mengalami perubahan warna yang menunjukan adanya aktifitas antioksidan. Meskipun terdapat perbedaan terhadap kedua sampel dimana daun patikan emas memiliki nilai antioksidan yang lebih tinggi dari daun bawang laut tapi dalam proses tersebut terlihar perubahan yang cukup signifikan. Perubahan warna tersebut merupakan hasil kualitatif, dimana adanya pengurangan intensitas warna pada larutan DPPH. Selain itu juga, secara kuantitatif hal tersebut ditunjukan dengan terjadinya penurunan serapan absorbansi larutan DPPH oleh panjang gelombang maksimumnya karena adanya pengurangan konsentrasi. Dalam hal ini pelepasan atom hidrogen oleh senyawa yang memiliki senyawa antioksidan membuat senyawa tersebut menjadi kekurangan elektron sehingga memungkinkan terbentuknya senyawa yang radikal. Akan tetapi dengan adanya kemampuan dari senyawa tersebut untuk bisa beresonansi yang membuat senyawa tersebut menjadi tidak reakif dalam mencari pasangan elektron dan membuat senyawa itu tidak stabil.

\section{Kesimpulan}

Daun patikan Emas positif mengandung beberapa senyawa metabolit sekunder seperti fenolik, flavonoid dan steroid sedangkan daun bawang laut mempunyai kandungan fenolik, flavonoid, steroid dan tannin. Hal itu dapat dilihat dengan adanya perubahan fisik metabolit sekunder serta kandungan total favonoid dan fenolik daun patikan emas lebih tinggi dari daun bawang laut. Aktivitas antioksidan dari daun patikan emas mempunyai nilai yang lebih tinggi dari pada aktivitas antioksi dan dari daun bawang laut. Kandungan antioksidan dari daun patikan emas diatas $50 \%$ sedangkan bawang laut mempunyai aktivitas hanya dibawah $50 \%$

\section{Daftar Pustaka}

Conde, E.E., M.C. Cadahia, G. Vallejo,B.F.D. Simon and J.R.G. Adrados.1997. Low Molecular Weight Polyphenol in Cork of QuerceusSuber. J. Agric. Food Chem. 45: 2695-2700.

Folin, O., and V. Ciocalteau. 1927. On Tyrosine and Tryptophane Determinations in Proteins. Journal of Biological Chemistry.73: 11471154

Harborne, J. B. 1987. Metode Fitokimia: Penuntun Cara Modern Menganalisis Tumbuhan. Institut 


\begin{abstract}
Teknologi Bandung (Diterjemahkan oleh Kosasih Padmawinata dan Iwang Soediro)
\end{abstract}

Meda, A., C.E. Lamien, M. Romito, J. Milliogo, and O.G. Nacoulina. 2005. Determination of the Total Phenolic, Flavonoid and Proline Content in Burkina Fasan Honey, as well as Their Radical Scavenging Activity. Journal Food Chemistry.91: 571-577

Sembiring, B.B., Ma'mundan E.I. Ginting. 2006. Pengaruh Kehalusan Bahandan Lama Ekstraksi Terhadap Mutu Ekstrak Temulawak (Curcuma xanthorriza Roxb). Buletin Penelitiandan Tanaman Obat. 17:53-58

Singleton, V.L. and J.A. Rossi. 1965. Colorimetry of Phenolic with Phosphomolybdic-Phosphotungstic Acid Reagen. American Journal Enology and Viticulture.16: 144-158

Sudarmadji, S., B. Haryono, dan Suhardi. 1989. Prosedur Analisis untuk Bahan Makanan dan Pertanian. Liberty, Yogyakarta. 